\title{
Estimating the effect of mastitis on the profitability of Irish dairy farms
}

\author{
U. Geary, ${ }^{* 1}$ N. Lopez-Villalobos, $†$ N. Begley, ${ }^{*}$ F. McCoy, ${ }^{\star} \ddagger$ B. O’Brien, ${ }^{\star}$ L. O’Grady,§ and L. Shalloo \\ *Livestock Systems Research Department, Animal and Grassland Research and Innovation Centre, Teagasc, Moorepark, Fermoy, \\ Co. Cork, Ireland \\ †Institute of Veterinary, Animal and Biomedical Science, Massey University, Palmerston North, New Zealand \\ $\ddagger$ Animal Health Ireland, Mainstreet, Carrick-on-Shannon, Co. Leitrim, Ireland \\ $\S S c h o o l$ of Agriculture, Food Science \& Veterinary Medicine, Veterinary Science Centre, Belfield Dublin 4, Ireland
}

\begin{abstract}
The objective of this paper was to estimate the effect of the costs of mastitis on the profitability of Irish dairy farms as indicated by various ranges of bulk milk somatic cell count (BMSCC). Data were collected from 4 sources and included milk production losses, cases treated, and on-farm practices around mastitis management. The Moorepark Dairy Systems Model, which simulates dairying systems inside the farm gate, was used to carry out the analysis. The cost components of mastitis that affect farm profitability and that were included in the model were milk losses, culling, diagnostic testing, treatment, veterinary attention, discarded milk, and penalties. Farms were grouped by 5 BMSCC thresholds of $\leq 100,000,100,001-200,000$, 200,001-300,000, 300,001-400,000, and >400,000 cells/ $\mathrm{mL}$. The $\leq 100,000$ cells $/ \mathrm{mL}$ threshold was taken as the baseline and the other 4 thresholds were compared relative to this baseline. For a 40-ha farm, the analysis found that as BMSCC increased, milk receipts decreased from $€ 148,843$ at a BMSCC $<100,000$ cells/ $\mathrm{mL}$ to $€ 138,573$ at a BMSCC $>400,000$ cells $/ \mathrm{mL}$. In addition, as BMSCC increased, livestock receipts increased by $17 \%$, from $€ 43,304$ at a BMSCC $<100,000$ cells/mL to $€ 50,519$ at a BMSCC $>400,000$ cells/ $\mathrm{mL}$. This reflected the higher replacement rates as BMSCC increased and the associated cull cow value. Total farm receipts decreased from $€ 192,147$ at the baseline $(<100,000$ cells $/ \mathrm{mL})$ to $€ 189,091$ at a BMSCC $>400,000$ cells $/ \mathrm{mL}$. Total farm costs increased as BMSCC increased, reflecting treatment, veterinary, diagnostic testing, and replacement heifer costs. At the baseline, total farm costs were $€ 161,085$, increasing to $€ 177,343$ at a BMSCC $>400,000$ cells $/ \mathrm{mL}$. Net farm profit decreased as BMSCC increased, from €31,252/ yr at the baseline to $€ 11,748 /$ yr at a BMSCC $>400,000$
\end{abstract}

Received August 23, 2011.

Accepted February 27, 2012.

${ }^{1}$ Corresponding author: una.geary@teagasc.ie
cells/mL. This analysis highlights the impact that mastitis has on the profitability of Irish dairy farms. The analysis presented here can be used to develop a "cost of mastitis" tool for use on Irish dairy farms to motivate farmers to acknowledge the scale of the problem, realize the value of improving mastitis control, and implement effective mastitis control practices.

Key words: mastitis, somatic cell count, profit, cost

\section{INTRODUCTION}

Mastitis has been identified as one of the most economically relevant diseases in Ireland by Animal Health Ireland via a Delphi study (More et al., 2010). Mastitis is a production disease that occurs when bacteria enter the udder and cause an infection. In response to this bacterial infection, the SCC of the cow will increase, with a SCC of 200,000 cells/mL generally accepted as an indicator of the presence of a mastitis infection (International Dairy Federation, 1997). Elevated SCC can also occur with stress or other infections; however, at an SCC of $>200,000$ cells $/ \mathrm{mL}$, the probability of a mastitis infection in one or more quarters (clinical or subclinical) is high. The losses associated with mastitis are often underestimated at the farm level due to the returns that the farmer fails to realize, including reduced milk production, higher rates of culling, increased mortality, and lower herd growth potential (Hogeveen and Østerås, 2005).

A large body of work has been undertaken internationally to estimate the cost of mastitis at the farm level. Halasa et al. (2007) carried out a review of the elements required to calculate the economics of mastitis and used this to develop a framework for future research. Huijps et al. (2008) developed a model to estimate the farm-specific costs of mastitis and used this model to develop a tool for use on Dutch dairy farms. Bar et al. (2008) developed an optimization and simulation model to estimate the cost of generic clinical mastitis in highyielding dairy cows in the United States. HagnestamNielsen and Ostergaard (2009) developed a simulation model to assess at the herd level the economic impact 
of reducing the incidence of clinical mastitis on Swedish dairy farms. Cha et al. (2011) developed a dynamic optimization and simulation model to estimate the cost of 3 different types of clinical mastitis at the individual cow level to help identify the economically optimal management decision for each type of mastitis. The cost components captured in these studies included milk production losses, diagnostics, treatment, labor, discarded milk, reduced milk yield, veterinary, culling, reduced milk and product quality, incidence of other diseases, and penalties.

Dairy farming in Ireland is characterized by low-cost, grass-based milk production, with an average farm size of 40 ha (O'Donnell et al., 2008). As Irish dairy farmers strive to expand in a post-quota environment (i.e., following abolition of the European Union milk quota system), a considered economic assessment of the farm is essential. Avoidable losses, such as those associated with mastitis, need to be minimized to ensure the sustainability of the farm business in a competitive world dairy market. The cost of mastitis and the effect it has on the profitability of the seasonal milk production system used on Irish dairy farms utilizing Irish-specific data has not, to date, been examined. This analysis can be used to highlight to Irish dairy farmers the true costs of this disease, thus motivating them to implement effective management practices to improve mastitis control and reduce the associated costs.

The objective of this paper was to estimate the effect of the costs of mastitis, as indicated by various ranges of bulk milk SCC (BMSCC), on the profitability of Irish dairy farms. The farms were characterized by 5 BMSCC thresholds of $\leq 100,000,100,001-200,000$, 200,001-300,000, 300,001-400,000, and >400,000 cells/ $\mathrm{mL}$. The $\leq 100,000$ cells $/ \mathrm{mL}$ threshold was taken as the baseline, and the other 4 thresholds were compared relative to this baseline.

\section{MATERIALS AND METHODS}

Biological, farm practice, and cost data were incorporated into the Moorepark Dairy Systems Model (MDSM; Shalloo et al., 2004; see description below) to estimate the effect of the costs of mastitis, as indicated by various ranges of SCC, on farm profitability. The cost components associated with mastitis accounted for in this analysis were (1) reduced milk production, (2) culling, treatment of (3) clinical and (4) subclinical mastitis cases, (5) veterinary visits, (6) discarded milk, and (7) penalties. The model estimated the total costs, total milk receipts, and net farm profit for an average dairy farm of 40 ha across each of the 5 BMSCC thresholds, $\leq 100,000, \quad 100,001-200,000, \quad 200,001-300,000$, 300,001-400,000, and >400,000 cells/mL. In Ireland, the SCC cut-off for collecting milk is $>400,000$ cells/ $\mathrm{mL}$, as per European Union (EU) regulations. The geometric mean SCC (required by EU regulations) for a farm is calculated throughout the year using several tests carried out each month. Common practice across Irish dairy processors is as follows: if the SCC exceeds 400,000 cells $/ \mathrm{mL}$ in 2 successive collections, then milk collection is discontinued until the SCC has been reduced. The baseline category of $\leq 100,000$ cells $/ \mathrm{mL}$ was used because the milk production loss data collected by Kelly (2009) was stratified by SCC category: 51-100, 101-200, 201-300, 301-400, >400 (× $10^{3}$ cells $/ \mathrm{mL}$ ). The Kelly analysis demonstrated that measurable milk production losses occurred even at a low SCC threshold of $<100,000$ cells $/ \mathrm{mL}$. In addition, this BMSCC threshold has been used elsewhere in the literature (Huijps et al., 2008).

\section{MDSM}

The MDSM (Shalloo et al., 2004) is a budgetary simulation model of a dairy farm. It allows investigation of the effects of varying biological, technical, and physical processes on farm profitability. The model integrates animal inventory, milk production, feed requirements, land and labor utilization, and an economic analysis of the production system. The default parameters of the MDSM were obtained from the results of experiments conducted in Moorepark (Co. Cork, Ireland) in recent years (Dillon et al., 1995; Horan et al., 2005; McCarthy et al., 2007). The model was run while holding the land area constant at 40 ha, based on the average farm size in Ireland (O'Donnell et al., 2008). Land area is treated as an opportunity cost, with additional land rented when required and leased out when not required for on-farm feeding of animals. The MDSM assumed that all male calves were sold and replacement heifers were reared on-farm from birth. Feed energy requirements are calculated in the MDSM based on the net energy required for milk production, maintenance, and BW change (Shalloo et al., 2004). Variable costs (fertilizer, contractor charges, medical and veterinarian fees, AI, silage, and reseeding), fixed costs (machinery maintenance and operating costs, farm maintenance, car, telephone, electricity, and insurance), and market prices (calf, cull cow, and milk) in the MDSM were based on up-to-date costs and prices. The MDSM also includes full labor expenses, where 1 labor unit costs $€ 22,855$ per yr $(1,848 \mathrm{~h})$. Basic routine costs in relation to mastitis prevention, such as machine maintenance, including liner change, teat disinfectant, machine washing, and dry cow therapy, are also incorporated in the model. The outputs in the model were disaggregated into receipts, costs, and other output indicators. 
Receipts. The gross milk price was $€ 0.262 / \mathrm{kg}$, based on a reference of $36.0 \mathrm{~g}$ of fat $/ \mathrm{kg}$ and $33.0 \mathrm{~g}$ of protein/ $\mathrm{kg}$ used by most Irish dairy manufacturers. Hence, milk payment was based on kilograms of fat (€3.134/kg) plus kilograms of protein (€6.268/kg). The calf and cull cow prices were based on average prices. Cull cows were valued at $€ 400$. Male calves were sold at 1 mo of age and valued at $€ 80$.

Costs. Veterinary costs (excluding mastitis costs) included routine animal treatments as well as compulsory annual tuberculosis and brucellosis testing of animals and drugs involved in correction of infertility problems in cows. Artificial insemination costs were based on 1.7 inseminations per conception, with each insemination costing €25.40 plus a service charge of $€ 11.43$. Costs associated with operating and servicing the milking parlor were included in the machinery operation and repair costs.

Other Output Indicators. The outputs from the model include financial indicators (operating cash flow, profit and loss account, and balance sheet) and physical outputs such as feed budget, nutrient balance sheet, and physical ratios. Farm net profit included total receipts less total costs, including a charge for full labor costs. The fixed cost distinguishes interest costs on an overdraft account from term liabilities. Interest earned on the cash flow in the current account is distinguished from other farm receipts.

Incorporating the costs associated with mastitis into the MDSM model affects the milk supply, feed demand, labor, and livestock movement components within the model. The costs of mastitis incorporated into the MDSM were diagnostics, antibiotics, veterinarian attention, milk production losses, culling, discarded milk, and penalties. Once these mastitis-related costs were incorporated into the model, the effect they had on farm profitability across each BMSCC threshold was examined.

\section{Data Sources and Mastitis-Related Cost Components}

The biological, farm practice, and cost data utilized in this analysis to estimate the cost of mastitis at various BMSCC thresholds on Irish dairy farms were taken from 4 national sources:

1. Data from the PhD thesis completed by Kelly (2009) were used, in which the association between SCC and milk yield on Irish dairy farms was examined.

2. The proportion of clinical mastitis cases treated was taken from a sample (78) of the Herd Ahead survey (Sayers, 2009) respondents, which cap- tured data on animal health and bio-security on 319 milk-recording Irish dairy farms.

3. The Irish Cattle Breeding Federation (ICBF, 2010) database was consulted for the sample of 319 dairy farms and data on the herd size, parity structure, and SCC status of the farms were collated.

4. The Mastitis Farm Practice survey was administered to a subset (78) of farmers who participated in the Herd Ahead program to gather data on diagnostics, treatment practices, discarded milk, and culling.

The data sources and data usage are summarized in Table 1. Utilizing these 4 data sources, farms were characterized by the 5 BMSCC thresholds stated previously. These thresholds represented herd averages for the year. For each BMSCC threshold, data were available on milk production losses, culling due to mastitis, diagnostic testing, clinical and subclinical cases treated, antibiotic and veterinary treatments, and discarded milk.

Milk Production Losses. Increasing SCC levels result in reduced milk production (Seegers et al., 2003). The effect of SCC on milk production in Ireland, used in this analysis, was based on the $\mathrm{PhD}$ thesis completed by Kelly (2009). This study examined the association between SCC and milk yield across parities, accounting for stage of lactation and calving month. In the analysis, individual cow test-day SCC records were extracted from the ICBF database over a 3-yr period from 2003 to 2005 . In total, 237,695 test-day records from 22,879 dairy cows in 357 herds were used for the analysis. Kelly (2009) estimated the association between milk yield and SCC using linear mixed models (Proc Mixed, SAS v9.1, SAS Institute Inc., Cary, NC) with milk yield as the dependent variable. The associations between SCC or $\log _{e}$ SCC and milk yield were undertaken within each SCC category for parities 1 to 5 . Analyses using preadjusted SCC were undertaken within parity. Confounding effects forced into each of the models as cow-level fixed effects were farm and calving month. The estimated average milk losses per day across the lactation for parity 1 to 5 cows across each of the 5 SCC thresholds are summarized in Table 2.

To calculate the milk production loss within each BMSCC threshold the average parity structure of the herds in each SCC threshold category was required. The milk production loss data were coupled with the average parity structure of Irish dairy farms for each BMSCC threshold, taken from the 319 Herd Ahead survey respondents. The average milk loss across lactation for each BMSCC threshold in this analysis (Table 2 ) was calculated by multiplying the milk production 
Table 1. Data sources, data used, and data application

\begin{tabular}{|c|c|c|}
\hline Data source & Data used & Data and application \\
\hline Kelly (2009) & Milk production losses associated with SCC across parities & $\begin{array}{l}\text { Milk production losses for each SCC category } \\
\text { for parity } 1 \text { to } 5 \text { cows (Kelly, 2009) } \\
\text { For the sample of Irish dairy farms that completed the Herd } \\
\text { Ahead survey (319; Sayers, 2009), the ICBF data in relation } \\
\text { to herd size, parity structure, and SCC were used. Using } \\
\text { this, the farms were categorized into each SCC threshold, } \\
\text { and the average parity structure for each SCC category was } \\
\text { calculated (Irish Cattle Breeding Federation; ICBF, 2010). } \\
\text { The average milk production loss for each category was } \\
\text { calculated by multiplying the Kelly data by the ICBF data }\end{array}$ \\
\hline Herd Ahead survey $(\mathrm{n}=319)$ & Number of mastitis cases treated in the last lactation & $\begin{array}{l}\text { Number of mastitis cases treated (Herd Ahead survey) } \\
\text { Herd size and SCC (ICBF). } \\
\text { Farms were categorized by SCC. Therefore, the proportion } \\
\text { of the herd treated for mastitis for each SCC threshold was } \\
\text { calculated by dividing the number of cases treated by the } \\
\text { herd size and averaging this across each SCC category }\end{array}$ \\
\hline $\begin{array}{l}\text { ICBF database, milk recording data } \\
\text { on the sample of } 78 \text { Herd Ahead } \\
\text { survey respondents }\end{array}$ & $\begin{array}{l}\text { Herd size } \\
\text { Parity structure } \\
\text { SCC count }\end{array}$ & $\begin{array}{l}\text { Used to calculate the proportions (e.g., proportion } \\
\text { of herd treated, proportion tested) } \\
\text { Used in the milk production loss calculations } \\
\text { Used to categorize the Herd Ahead survey respondents }\end{array}$ \\
\hline $\begin{array}{l}\text { Mastitis Farm Practice survey }(\mathrm{n}=78) \\
\text { (subsample of the Herd Ahead survey } \\
\text { sample) }\end{array}$ & $\begin{array}{l}\text { In the last lactation: } \\
\text { Number of bulk tank and individual cow milk cultures } \\
\text { Number of subclinical mastitis cases treated } \\
\text { Proportion of cases treated with intramammary } \\
\text { tubes only, i.v. antibiotics only, both } \\
\text { intramammary and i.v., and pain relief } \\
\text { Whether antibiotic residue milk, high } \\
\text { SCC milk, or both, is fed to calves } \\
\text { Number of cows culled due to mastitis }\end{array}$ & $\begin{array}{l}\text { Herd size and SCC (ICBF) } \\
\text { The sample was stratified by SCC categories. As above, } \\
\text { the proportion of bulk tank milk cultures, individual cow } \\
\text { milk cultures, subclinical cases treated, cases treated with } \\
\text { intramammary tubes only, treated with i.v. antibiotics only, } \\
\text { treated with intramammary tubes and i.v. together, treated } \\
\text { with pain relief, farms discarding milk and cows culled due } \\
\text { to mastitis were calculated across each SCC category }\end{array}$ \\
\hline
\end{tabular}

with pain relief, farms discarding milk and cows culled due 


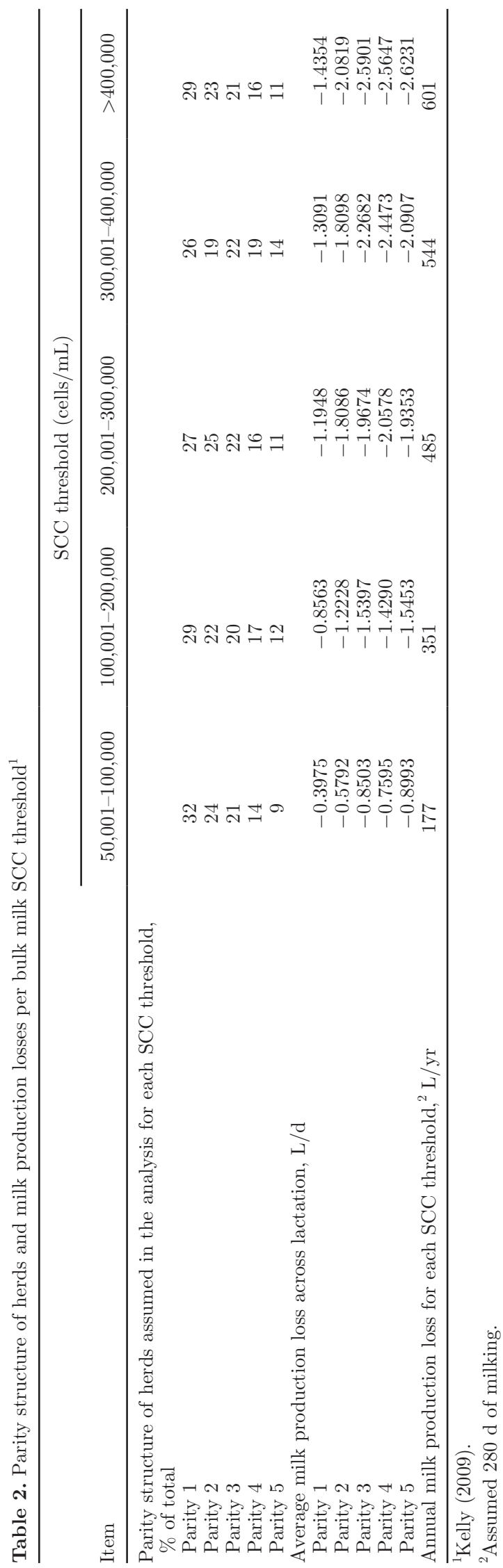

loss per day by the average parity structure of each BMSCC threshold and multiplying this by the DIM. This is summarized by

$$
\begin{aligned}
& \text { Milk loss across the lactation }<100,000 \text { cells } / \mathrm{mL}= \\
& {\left[\left(\mathrm{MLP}^{1} \times \% \mathrm{P}^{1}\right)+\left(\mathrm{MLP}^{2} \times \% \mathrm{P}^{2}\right)+\left(\mathrm{MLP}^{3} \times \% \mathrm{P}^{3}\right)\right.} \\
& \left.+\left(\mathrm{MLP}^{4} \times \% \mathrm{P}^{4}\right)+\left(\mathrm{MLP}^{5} \times \% \mathrm{P}^{5}\right)\right] \times 280
\end{aligned}
$$

where $\mathrm{MLP}^{1}$ to $\mathrm{MLP}^{5}=$ milk loss in parity 1 to 5 , respectively, for $\mathrm{SCC}<100,000$ cells $/ \mathrm{mL}$, and $\% \mathrm{P}^{1}$ to $\mathrm{P}^{5}=$ proportion of herd that are parity 1 to 5 , respectively.

We assumed the average number of days in milk to be $280 \mathrm{~d}$, which was calculated using a mean herd calving date of February 20 and a herd dry-off date of December 10.

Clinical Mastitis Cases Treated. The proportion of clinical mastitis cases treated was sourced from the Herd Ahead survey. The Herd Ahead program comprised a comprehensive survey and an on-farm monitoring program for infectious disease at the farm level in Ireland. In total, the survey included 319 participants, which were randomly selected from the ICBF database; all farms were members of HerdPlus and were milk recording. The Herd Ahead survey collected data on the number of mastitis cases treated in the last lactation, classifying them as mastitis or severe mastitis. Data on the mastitis cases treated for a subset of the sample (78) was used. These data were coupled with the ICBF data for the 78 respondents on herd size and BMSCC to calculate the proportion of the herd treated for clinical mastitis across each of the BMSCC thresholds. Of the 78 respondents, 14 were categorized as $<100,000$ cells/mL, 39 as 100,001-200,000 cells/mL, 17 as 200,001-300,000 cells/mL, and 8 as 300,001-400,000 cells $/ \mathrm{mL}$. Because none of the survey participants met the $>400,000$ cells $/ \mathrm{mL}$ BMSCC threshold, the difference between the 200,001-300,000 cells $/ \mathrm{mL}$ and the $300,001-400,000$ cells $/ \mathrm{mL}$ was added to the $300,001-$ 400,000 cells $/ \mathrm{mL}$ threshold to extrapolate the $>400,000$ cells $/ \mathrm{mL}$ assumptions. This assumption is discussed in more detail in the Discussion. The proportion of the herd treated for clinical mastitis across each of the BMSCC thresholds ranged between 11 and 38\%, as presented in Table 3.

$\boldsymbol{I} \boldsymbol{C B F}$. Data relating to herd size, parity, and SCC for each of the Herd Ahead survey respondents were provided by ICBF and combined with the Herd Ahead and Mastitis Farm Practice data. The 305-d records were computed based on the standard lactation curve method (Olori and Galesloot, 1999). Restrictions used for the current data were comparable to those used in 
Table 3. Treatment practice assumptions (proportion, \%, unless otherwise noted) per bulk milk SCC threshold

\begin{tabular}{|c|c|c|c|c|c|c|}
\hline \multirow[b]{2}{*}{ Item } & \multicolumn{5}{|c|}{ SCC threshold $\left(\times 10^{3}\right.$ cells $\left./ \mathrm{mL}\right)$} & \multirow[b]{2}{*}{$P$-value } \\
\hline & $\begin{array}{c}<100 \\
\text { (Baseline) }\end{array}$ & $100-200$ & $200-300$ & $300-400$ & $>400^{1}$ & \\
\hline Farms carrying out bulk tank milk cultures ${ }^{3}$ & 1 & 2 & 1 & 1 & 1 & NS \\
\hline Farms carrying out individual milk cultures ${ }^{3}$ & 1 & 3 & 1 & 4 & 8 & NS \\
\hline \multicolumn{7}{|l|}{ Treatment practices } \\
\hline Cases treated using intramammary tubes only ${ }^{3}$ & 59 & 90 & 73 & 55 & 37 & NS \\
\hline Cases treated using injectable antibiotics only ${ }^{3}$ & $5^{\mathrm{a}}$ & $1^{\mathrm{a}}$ & $6^{\mathrm{a}}$ & $19^{\mathrm{b}}$ & 32 & $*$ \\
\hline Cases treated using both ${ }^{3}$ & 37 & 9 & 21 & 26 & 31 & NS \\
\hline Cases treated using pain relief ${ }^{3}$ & 21 & 21 & 18 & 13 & 7 & NS \\
\hline Farms discarding milk ${ }^{3}$ & $12^{\mathrm{a}}$ & $17^{\mathrm{ab}}$ & $24^{\mathrm{bc}}$ & $32^{\mathrm{c}}$ & 39 & $* *$ \\
\hline \multicolumn{7}{|c|}{$\begin{array}{l}{ }^{a-c} \text { Means within a row with different superscripts differ. } \\
{ }^{1} \text { A }\end{array}$} \\
\hline
\end{tabular}

the national genetic evaluations. Briefly, when cumulative milk yields were $<2,500 \mathrm{~kg}$ or milk fat or protein yield was $<40 \mathrm{~kg}$, the records were removed. Age at first calving was restricted to between 640 and 1,095 d. Cows with lactation lengths $<170$ and $>600 \mathrm{~d}$ were removed, and calving intervals were required to be at least $300 \mathrm{~d}$ but not greater than $690 \mathrm{~d}$.

Mastitis Farm Practice Data. Data relating to farm practice on Irish dairy farms were not readily available in the literature; therefore, a short survey relating to mastitis farm practice was administered to participants of the Herd Ahead program. Of the 319 Herd Ahead participants, 78 completed the Mastitis Farm Practice survey and were classified by BMSCC as outlined earlier. The survey consisted of 10 questions that related to diagnostic testing, treatment practices, discarded milk, and culling. The survey responses were coupled with the corresponding herd size, parity, and BMSCC data collected from the ICBF database. The data for each cost component are summarized in Table 3.

Discarded Milk. For the duration of antibiotic treatment and for a defined period after (milk withdrawal period), milk from treated cows cannot be sold. This is to avoid antibiotic residues in the milk supplied to processors. In this analysis, milk was assumed to be discarded for $5 \mathrm{~d}$ ( $3 \mathrm{~d}$ treatment, $2 \mathrm{~d}$ posttreatment). An alternative to discarding this antibiotic milk is feeding it to calves (in place of calf milk replacer). The
Mastitis Farm Practice survey showed that a large proportion of respondents fed high SCC milk or antibiotic residue milk to calves. This is only feasible, however, until the calves are turned out to grass. In this analysis, we assumed that all discarded milk could be fed to calves from January to May until calves were weaned; thereafter, the milk was discarded and losses were incurred. The proportion of farms discarding milk across each BMSCC threshold is summarized in Table 3 and is based on the clinical and subclinical cases treated.

Penalties. In Ireland, milk that is collected by the processor and found to have a BMSCC $>400,000$ cells/mL incurs a penalty, which was included in the analysis. Utilizing data from Berry et al. (2006), which documented the monthly trend in geometric mean SCC, a weighting was applied to the monthly SCC in the model to account for the seasonality of SCC.

\section{Cost Assumptions}

The costs included in this analysis were taken from published reference price lists and consultation with veterinary practices. Table 4 summarizes the cost assumptions. The treatment costs were sourced via consultation with Irish veterinarians. The costs for intramammary tubes were based on a full course of treatment over $3 \mathrm{~d}$. The costs for injectable antibiotic were based on intramuscular antibiotic costs, intravenous antibiotic costs, and the proportion of cases treated 
Table 4. Costs assumed in the analysis

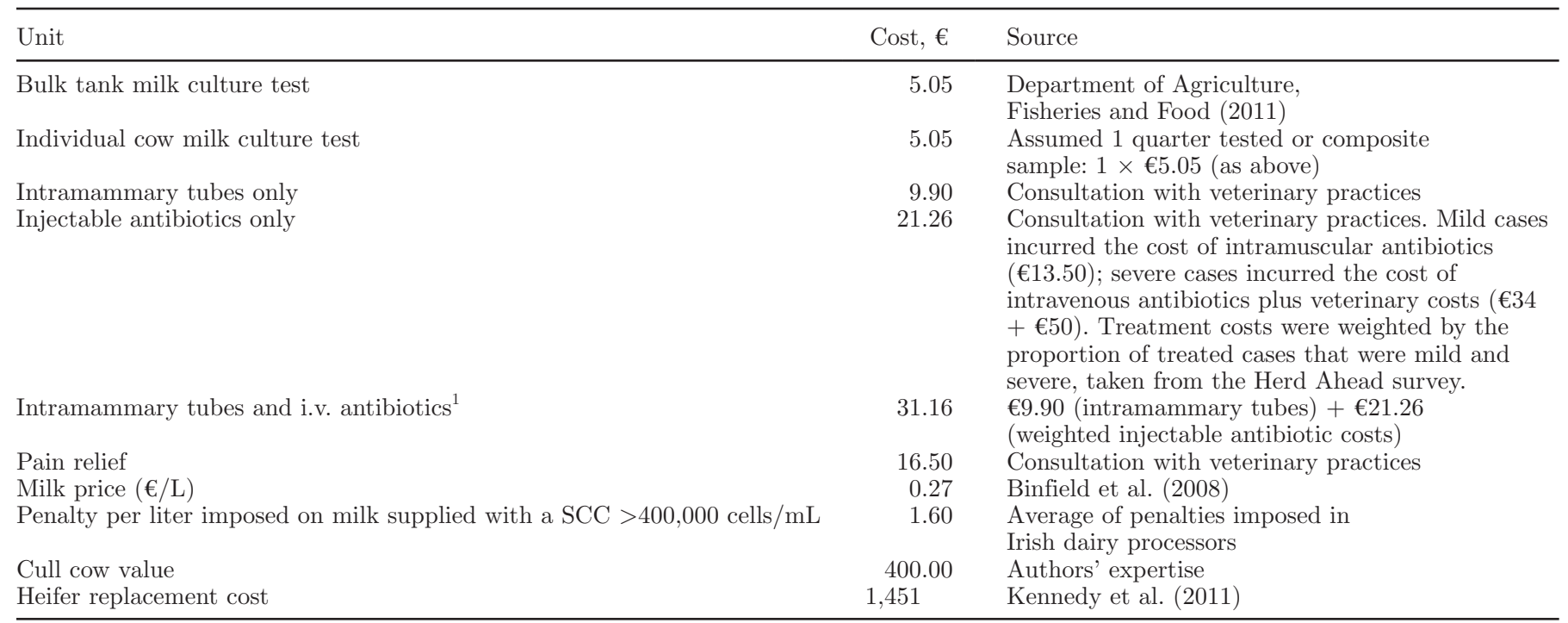

${ }^{1}$ Source: Herd Ahead survey (Sayers, 2009). Treatment costs were weighted by mild and severe. We assumed that mild cases treated with injectable antibiotics incurred the cost of intramuscular antibiotics, and severe cases treated with injectable antibiotics incurred the cost of i.v. antibiotics plus veterinary costs.

that were separated into mastitis and severe mastitis from the Herd Ahead survey. We assumed that mastitis cases treated with injectable antibiotics referred to i.m. antibiotics, and that severe mastitis cases treated with injectable antibiotics referred to i.v. antibiotics (i.e., administered by the veterinarian). Data from the Herd Ahead survey estimated that $89 \%$ of cases treated were mastitis cases and $11 \%$ of cases treated were severe mastitis cases. Weighting the antibiotic costs by their respective usage generated an average injectable antibiotic cost of $€ 21.26$. The treatment costs for each SCC threshold based on treatment practices (Table 3) and treatment costs (Table 4) were estimated at $€ 18.21$, $€ 11.85$, €15.07, €17.61, and €20.51 for $<100,000$ cells/ $\mathrm{mL}, 100,001-200,000$ cells/mL, 200,001-300,000 cells/ $\mathrm{mL}, 300,001-400,000$ cells $/ \mathrm{mL}$, and $>400,000$ cells $/ \mathrm{mL}$, respectively.

The biological and cost data outlined above were incorporated into the MDSM. For each of the 5 BMSCC thresholds, the effect that mastitis costs have on farm profit was estimated while holding land area constant.

\section{RESULTS}

The results for each of the 5 BMSCC threshold categories are presented in Table 5 (physical outputs) and Table 6 (financial outputs). In this analysis, the BMSCC threshold of $<100,000$ cells $/ \mathrm{mL}$ was assumed as the baseline and all results are presented relative to this base.

\section{Physical Outputs}

In this analysis, land area was fixed at 40 ha. The number of cows calving in the base model $(\leq 100,000$ cells $/ \mathrm{ml}$ ) was 94 (Table 5 ). As the BMSCC increased, the number of cows calving increased stepwise to 101 cows at a BMSCC $>400,000$ cells $/ \mathrm{mL}$. The increase in cows calving reflected the decrease in milk yield per cow, which reduced the energy demand per cow. The model assumed that the same level of feed was used irrespective of BMSCC level; therefore, when milk yield per cow decreased, the herd cow numbers increased to maintain the level of feed. The baseline stocking rate was 2.62 cows/ha, increasing to 2.70 cows/ha at a BMSCC $>400,000$ cells $/ \mathrm{mL}$. The kilograms of milk delivered in the base model $(\leq 100,000$ cells $/ \mathrm{mL})$ was $532,122 \mathrm{~kg}$, decreasing to $513,596 \mathrm{~kg}$ for the BMSCC threshold of $>400,000$ cells $/ \mathrm{mL}$. The decrease in milk sales as the number of cows calving and BMSCC increased reflected the decrease in milk production as BMSCC increased as well as the replacement of highproducing multiparous cows with primiparous cows. The kilograms of milk solids (MS) produced decreased as SCC increased. In the baseline analysis, $37,530 \mathrm{~kg}$ of MS was delivered, decreasing to $36,190 \mathrm{~kg}$ of MS at a BMSCC $>400,000$ cells $/ \mathrm{mL}$. The MS per cow and per hectare were $411 \mathrm{~kg}$ and $938 \mathrm{~kg}$, respectively, for the baseline model, decreasing to $370 \mathrm{~kg}$ of MS per cow and $905 \mathrm{~kg}$ of MS per hectare at a BMSCC $>400,000$ cells $/ \mathrm{mL}$. The replacement rate in the baseline analysis was $19 \%$, with replacement heifer costs of $€ 25,550$ and 
Table 5. Effect of mastitis on the physical outputs of Irish dairy farms across 5 bulk milk SCC (BMSCC) thresholds, holding land area constant

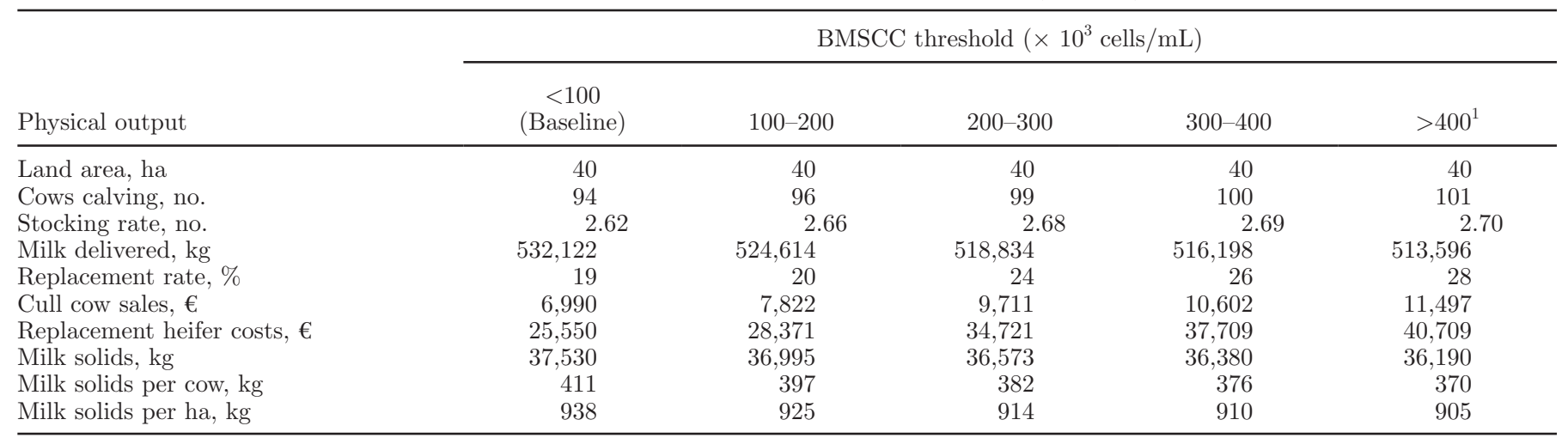

${ }^{1}$ The physical outputs for the $>400,000$ cells $/ \mathrm{mL}$ BMSCC category were based on extrapolated assumptions using the data from the $200,000-$ 300,000 cells $/ \mathrm{mL}$ and the $300,000-400,000$ cells/mL categories.

a cull cow value of $€ 6,990$. This increased to a replacement rate of $28 \%$ at a BMSCC $>400,000$ cells $/ \mathrm{mL}$, with a replacement heifer cost of $€ 40,709$ and a cull cow value of $€ 11,497$.

\section{Financial Outputs}

Milk Receipts. At a BMSCC of $\leq 100,000$ cells/mL, total milk receipts of $€ 148,843$ were generated (Table $6)$. Increasing the BMSCC decreased milk receipts to $€ 138,573$ for BMSCC $>400,000$ cells $/ \mathrm{mL}$. This corresponded to a reduction in milk receipts of $€ 2,126$, $€ 4,293, € 7,564$, and $€ 10,270$ for the differing BMSCC categories compared with the baseline.

Livestock Receipts. At a BMSCC of $\leq 100,000$ cells/mL, total livestock receipts of $€ 43,304$ were generated (Table 6). Increasing the BMSCC resulted in an increase in livestock receipts due to the increased replacement rate and the associated cull cow value.
Livestock receipts increased to $€ 50,519$ at a BMSCC $>400,000$ cells $/ \mathrm{mL}$, corresponding to an increase of $€ 7,215$ compared with the baseline.

Total Farm Receipts. Total farm receipts included farm and livestock receipts. At an SCC $\leq 100,000$ cells/ $\mathrm{mL}$, the total farm receipts were $€ 192,147$, equivalent to 36.1 cents $/ \mathrm{kg}$ and $€ 4,804 / \mathrm{ha}$. Increasing the BMSCC to $>400,000$ cells $/ \mathrm{mL}$ resulted in total farm receipts decreasing to $€ 189,091$, equivalent to 36.8 cents $/ \mathrm{kg}$ and $€ 4,727 /$ ha. This corresponded to a reduction in total farm receipts of $€ 3,056$ compared with the baseline.

Total Farm Costs. Within total farm costs, all costs associated with mastitis were included (diagnostic, treatment, veterinary, heifer replacement). At the baseline BMSCC, the total farm costs were $€ 161,085$, equivalent to 30.3 cents $/ \mathrm{kg}$ and $€ 4,027 / \mathrm{ha}$. As the BMSCC increased, total farm costs increased to $€ 177,343$ at a BMSCC of $>400,000$ cells $/ \mathrm{mL}$, equivalent to 34.5 cents/kg and $€ 4,434 /$ ha. This corresponded to an in-

Table 6. Effect of mastitis on the financial outputs of Irish dairy farms across 5 bulk milk SCC (BMSCC) thresholds, holding land area constant

BMSCC threshold $\left(\times 10^{3}\right.$ cells $\left./ \mathrm{mL}\right)$

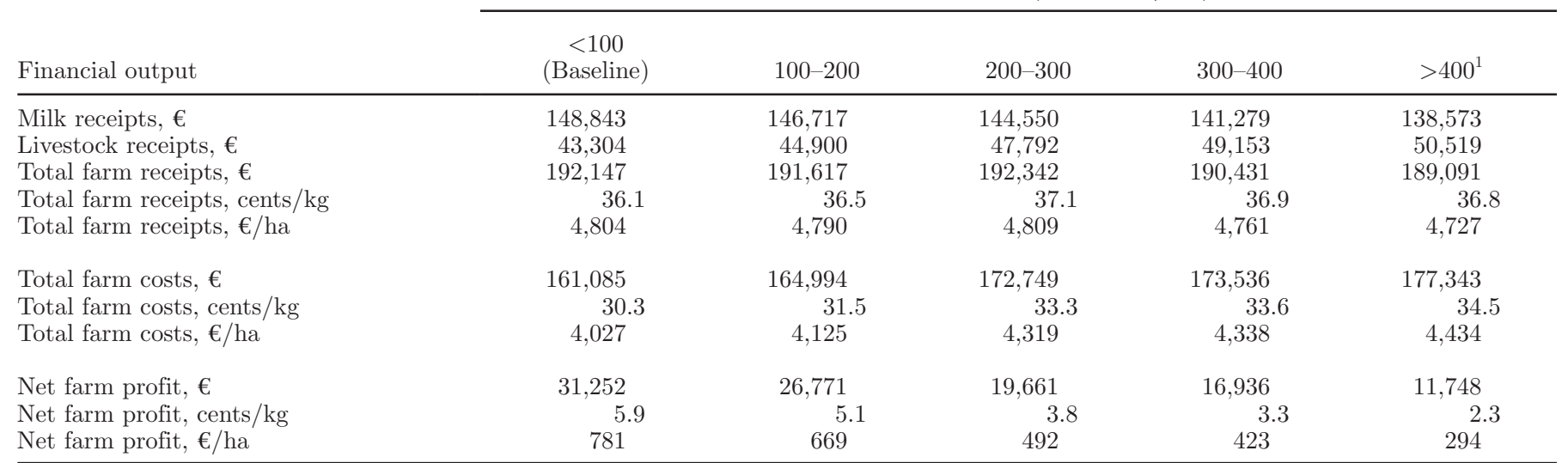

${ }^{1}$ The financial outputs for the $>400,000$ cells/mL BMSCC category were based on extrapolated assumptions using the data from the 200,000300,000 cells $/ \mathrm{mL}$ and the $300,000-400,000$ cells $/ \mathrm{mL}$ categories. 
crease in total farm costs of $€ 3,909, € 11,664$, €12,451, and $€ 16,258$ for the increasing BMSCC categories, respectively, compared with the baseline.

Net Farm Profit. As the BMSCC increased, the annual net farm profit generated decreased. At a BMSCC $<100,000$ cells $/ \mathrm{mL}$ (baseline), the net farm profit was €31,252/yr, equivalent to 5.9 cents $/ \mathrm{kg}$ and €781/ ha. At a BMSCC $>400,000$ cells $/ \mathrm{mL}$, the net farm profit generated was $€ 11,748 / \mathrm{yr}$, equivalent to a net profit of 2.3 cents $/ \mathrm{kg}$ and $€ 294 /$ ha. This corresponded to a reduction in net farm profit of $€ 4,481$, €11,591, $€ 14,316$, and $€ 19,504$ for the increasing BMSCC categories, respectively, compared with the baseline.

\section{DISCUSSION}

The objective of this paper was to identify the costs associated with mastitis, as indicated by various ranges of BMSCC, and to use this to demonstrate the effect that mastitis costs have on farm profitability. This analysis demonstrated that as BMSCC increased, milk production was reduced and the proportion of the herd culled due to mastitis increased. As BMSCC increased, milk receipts decreased; as a result, total farm receipts were also lower with higher BMSCC thresholds. In addition, as BMSCC increased, the total farm costs increased as more cows were treated and proportionately more cows were culled. As a result, as BMSCC increased from $\leq 100,000$ to $>400,000$ cells $/ \mathrm{mL}$, net farm profit decreased by $€ 19,504$. In a post-quota environment, mastitis would impede the rate and extent of expansion, because essential profits required to facilitate expansion would be lost. The model developed in this paper is flexible and could be used to conduct analysis for any dairy farm in Ireland utilizing farmspecific data.

The model presented here is feed driven, whereby the same level of feed is used in the model irrespective of the BMSCC threshold. Therefore, in the analysis presented here, as BMSCC increased, milk production decreased, which in turn reduced the feed requirement. As a result, the cow numbers increased to maintain the level of feed in the system. If cow numbers were held constant in the analysis, the losses associated with high BMSCC would be higher than those presented in this study. Evidence on reduced feed efficiency as a result of mastitis infection is currently not available. If this were incorporated into the analysis, however, the losses would again be higher.

\section{Data}

The data used in the analysis presented in this paper were taken from several national sources. Milk produc- tion losses were based on national milk recording data. Very little data in relation to mastitis farm practice are available in Ireland and so the Mastitis Farm Practice survey was developed and administered to 78 Irish dairy farmers. Although the sample size was small, the data collected on diagnostic testing, clinical and subclinical mastitis cases treated, treatment practices, discarded milk, and culling were indicative of treatment practices in Ireland and filled an existing data gap. Nevertheless, one inherent weakness of this data set was that none of the survey respondents had a BMSCC of $>400,000$ cells $/ \mathrm{mL}$. Therefore, we had to extrapolate the data used for the $>400,000$ cells $/ \mathrm{mL}$ category.

It should be noted that the largest cost components in any cost of mastitis analysis are milk production losses and culling costs, as demonstrated in this paper and by Huijps et al. (2008). Although the costs associated with testing and treatment were included for completeness, their respective effect on net farm profit would be minimal relative to culling and lost milk production costs. Therefore, although questions exist around the robustness of the assumptions for the $>400,000$ cells $/ \mathrm{mL}$ category, the relative importance to the analysis should be considered for each cost component, with lost milk production and culling carrying the greatest weight.

\section{Milk Production Losses}

The milk production losses associated with BMSCC used in this analysis were sourced from the ICBF milk recording database. Milk production losses have been included in a large proportion of published analyses of mastitis costs. Kossaibati and Esslemont (1997) estimated milk losses for mild and severe cases of mastitis at 247 and $450 \mathrm{~L}$, respectively. These losses are similar to the ranges assumed in this paper (177-601 L). Larcombe and Shephard (2004) estimated the milk yield loss at $3.4 \%$ of the $300-d$ milk yield $(5,500 \mathrm{~L})$ per clinical case for Australian dairy farms (187 L). The Seasonal Approach to Managing Mastitis (SAMM) cost-of-mastitis calculator developed in New Zealand (Malcolm et al., 2005) estimated milk production losses per average mixed-age cow in the national herd at $88.5 \mathrm{~L}$ based on the New Zealand National Herd Testing database. This estimated loss in milk production is low relative to estimates in the international literature. Hultgren and Svensson (2009) estimated yield losses for primiparous cows to range between 0 and $9 \%(0-691 \mathrm{~L})$ of the $305-\mathrm{d}$ milk yield $(7,675 \mathrm{~kg})$ and for multiparous cows the range was between 0 and $11 \%(0-865 \mathrm{~L})$ of the $305-\mathrm{d}$ milk yield $(7,862 \mathrm{~kg})$. Bar et al. (2007) found with US data that a cow with one or more clinical mastitis episodes in the previous lactation 
produced $1.2 \mathrm{~kg} / \mathrm{d}$ less milk over the whole lactation. Bar et al. (2008) found that milk yield losses accounted for $64 \%$ of the average cost of a clinical mastitis case utilizing New York State data. More recently, Cha et al. (2011) estimated that $72.4 \%$ of the total cost per case for gram-negative clinical mastitis was attributed to milk production losses. The literature highlights the variability in milk production losses between countries and their respective production systems as well as the manner in which these losses can be incorporated into cost of mastitis analyses.

\section{Culling}

In Ireland, data on the number of cows culled were accurate, but the reasons for culling were less so. This resulted in a requirement to complete a Mastitis Farm Practice survey to collect this information. Similarly, in New Zealand, the recording of culling and the reason for culling is poor, and thus, Malcolm et al. (2005) utilized data from the Livestock Improvement Corporation (LIC) Reproductive Performance report in their SAMM model. Based on these data, the percentage of the herd culled due to mastitis was estimated by Malcolm et al. (2005) at 1.3\%, which the researchers agreed underestimated culling due to mastitis. The average cull cow cost was estimated at $\mathrm{NZ} \$ 477$ (equivalent to $€ 276$ ), which is lower than that used in this analysis (€400). A possible explanation for this difference could be that the New Zealand cull cow cost is based on data from 2005 and may be outdated. Similarly, the cost associated with culling a cow in the Netherlands was $€ 480$ (Huijps et al., 2008), which is significantly lower than in Ireland. This cost captures slaughter price, replacement costs, and retention pay off. The heifer replacement cost alone in this paper was $€ 1,451$ (Kennedy et al., 2011); this is inclusive of labor, land, initial value of the calf (€350), and other variable and fixed costs. It reflects the costs involved in rearing replacement heifers from birth to calving and so helps explain the difference between the Dutch and Irish culling figures. Culling was not explicitly incorporated directly in the Hagnestam-Nielsen and Ostergaard (2009) cost of mastitis model (Swedish). Instead, culling was accounted for through reduced milk production, with decreased milk yield causing a shortened insemination period, which had the effect of increasing the risk of voluntary culling. This research highlights the strong association between mastitis and culling and so the importance of the inclusion of this cost component in this analysis. The literature demonstrates the many ways of incorporating culling into the analysis.

\section{Labor}

The costs of labor were excluded from the analysis presented here for several reasons but predominantly due to the lack of specific Irish data on the labor time required to treat and manage mastitis herds. Many studies have been published with an estimate of the additional labor time required to treat and manage a mastitis incidence but the variation across studies is large, from15 min (Vetgate Manual; Mastitis Management and Milk Quality Control Workshop, New Zealand, 2006) to $45 \mathrm{~min}$ (Huijps et al., 2008). Halasa et al. (2007) found that the opportunity costs of labor differ from farm to farm. If the labor is hired, then the opportunity cost is the cost of that labor, whereas if the labor comes from the farmer's free time, then the opportunity cost is zero. Because of the scale of Irish dairy farms, most farms are run by the farmer without hired labor. Huijps et al. (2009) also found from an analysis of the relative importance farmers assign to each of the cost factors of mastitis, additional labor was found to be of low importance. Based on these findings labor was not included in this analysis. In an expanding dairy industry, however, an increased incidence of mastitis could reduce the number of cows that one individual could handle and labor would then have a considerable economic effect on SCC levels.

\section{Quota}

In the analysis presented in this paper, land was assumed as the limiting factor at 40 ha. This is reflective of a post-quota environment in which milk production in the EU will no longer be constrained (for the first time since 1984), thus creating significant opportunities for Irish and EU dairy farmers. This policy change, combined with reduced levels of market support, means that Irish dairy farmers will be exposed to increased milk price volatility in the future. This presents a challenge: to expand while insulating against volatility. Therefore, it is essential that Irish dairy farmers reduce avoidable on-farm costs and losses, as demonstrated in this analysis.

\section{Model}

Each of the cost components included in this analysis and incorporated into the MDSM model captured the effect this disease has on a dairy farm. Dependent upon BMSCC category, milk production losses were deducted from the volume of milk produced on the farm. The reduced milk production had an effect in the model of a reduced feed requirement. Although cow numbers 
increased to utilize the available feed, higher culling at higher SCC thresholds resulted in increased revenue from cull cow sales and higher replacement heifer costs. Diagnostics, veterinary, and treatment costs were applied and incorporated into the animal health cost calculations. The model simulated the effects of mastitis on dairy farm production, culling, costs, revenue, and finally profitability.

\section{Future Applications}

Mastitis has implications at processor level as well as at farm level, and these costs have not been quantified in this analysis. Hogeveen and Østerås (2005) identified the costs of mastitis or high SCC at the processor level, such as reduced milk quality, reduced product yield, flavor change, and reduced shelf life. Each of these factors will affect customer satisfaction, product rating, product market value, and ultimately the returns to processors and producers. It is commonly agreed that high SCC in milk reduces the yield and quality of cheese (Klei et al., 1998; Ma et al., 2000) Utilizing the processing sector model developed by Geary et al. (2010), the effect of these factors on processor revenue, net milk value (total revenue - total costs), milk price paid to farmers, and component values of milk (value per kilogram of fat and protein) can be estimated. This analysis will be investigated using the Moorepark Processing Sector Model (MPSM; Geary et al., 2010).

In addition, the data presented in this paper can be used to build an on-farm "cost of mastitis" calculator similar to that developed by Huijps et al. (2008) for Dutch dairy farms, the SAMM calculator developed for New Zealand dairy farmers, and the Countdown Down Under calculator developed for Australian dairy farmers.

\section{CONCLUSIONS}

Mastitis resulted in a considerable reduction in profit on Irish dairy farms decreasing from €31,252 at a BMSCC of $<100,000$ cells/mL to $€ 11,748$ at a BMSCC of $>400,000$ cells $/ \mathrm{mL}$. An analysis conducted by Berry et al. (2006) to document temporal trends in BMSCC on Irish dairy herds between 1994 and 2004 found the national geometric mean SCC to be 250,937 cells $/ \mathrm{mL}$ in 2004. Based on the analysis carried out in this study, at this SCC level Irish dairy farms would be sustaining large losses. In order for Irish dairy farmers to prosper in a post-quota environment, which will be highly competitive, unnecessary on-farm costs and losses need to be minimized. Quantifying the costs of mastitis to demonstrate the losses occurring on Irish dairy farms is an important step in motivating farmers to acknowl- edge the scale of the problem and implement effective management practices aimed at improving mastitis control and reducing the associated costs.

\section{ACKNOWLEDGMENTS}

The authors thank Paddy Kelly (Munster Cattle Breeding Group, Co. Cork, Ireland) for use of his $\mathrm{PhD}$ thesis results in this analysis. Many thanks to Regina Sayers, Noel Byrne, and Eugene O'Doherty (all of Teagasc, Moorepark, Co. Cork, Ireland) for use of their Herd Ahead data and for their support in administering the Mastitis Farm Practice surveys and compiling the final dataset. The authors also thank ICBF (Bandon, Co. Cork, Ireland) for providing the milk production file. The authors acknowledge the financial support of the Department of Agriculture, Fisheries and Food (Ireland) through the Research Stimulus Fund (RSF 10-714).

\section{REFERENCES}

Bar, D., Y. T. Grohn, G. Bennett, R. N. Gonzalez, J. A. Hertl, H. F. Schulte, L. W. Tauer, F. L. Welcome, and Y. H. Schukken. 2007. Effect of repeated episodes of generic clinical mastitis on milk yield in dairy cows. J. Dairy Sci. 90:4643-4653.

Bar, D., L. W. Tauer, G. Bennett, R. N. González, J. A. Hertl, Y. H. Schukken, H. F. Schulte, F. L. Welcome, and Y. T. Gröhn. 2008. The cost of generic clinical mastitis in dairy cows as estimated using dynamic programming. J. Dairy Sci. 91:2205-2214.

Berry, D. P., B. O'Brien, E. J. O'Callaghan, K. O. O'Sullivan, and W. J. Meaney. 2006. Temporal trends in bulk tank somatic cell count and total bacterial count in Irish dairy herds during the past decade. J. Dairy Sci. 89:4083-4093.

Binfield, J., T. Donnellan, K. Hanarahan, and P. Westhoff. 2008. FAPRI-Ireland Baseline 2008: Outlook for EU and Irish Agriculture. FAPRI-Ireland Partnership Teagasc, Carlow, Ireland.

Cha, E., D. Bar, J. A. Hertl, L. W. Tauer, G. Bennett, R. N. González, Y. H. Schukken, F. L. Welcome, and Y. T. Gröhn. 2011. The cost and management of different types of clinical mastitis in dairy cows estimated by dynamic programming. J. Dairy Sci. 94:4476-4487.

Department of Agriculture, Fisheries and Food. 2011. Regional veterinary laboratory test and price list. Accessed Aug. 23, 2011. http:// www.agriculture.gov.ie/animalhealthwelfare/laboratoryservices/ regionalveterinarylaboratories/testandpricelist/.

Dillon, P., S. Crosse, G. Stakelum, and F. Flynn. 1995. The effect of calving date and stocking rate on the performance of springcalving dairy cows. Grass Forage Sci. 50:286-299.

Geary, U., N. Lopez-Villalobos, D. J. Garrick, and L. Shalloo. 2010 Development and application of a processing model for the Irish dairy industry. J. Dairy Sci. 93:5091-5100.

Hagnestam-Nielsen, C., and S. Ostergaard. 2009. Economic impact of clinical mastitis in a dairy herd assessed by stochastic simulation using different methods to model yield losses. Animal 3:315-328.

Halasa, T., K. Huijps, O. Osteras, and H. Hogeveen. 2007. Economic effects of bovine mastitis and mastitis management: A review. Vet. Q. 29:18-31.

Hogeveen, H., and O. Østerås. 2005. Mastitis management in an economic framework. Pages 41-52 in Proc. 4th IDF Int. Dairy Conf.: Mastitis in Dairy Production: Current Knowledge and Future Solutions. Wageningen Academic Publishers, Wageningen, the Netherlands.

Horan, B., P. Dillon, P. Faverdin, L. Delaby, F. Buckley, and M. Rath. 2005. The interaction of strain of Holstein-Friesian cows and pas- 
ture-based feed systems on milk yield, body weight, and body condition score. J. Dairy Sci. 88:1231-1243.

Huijps, K., H. Hogeveen, T. J. G. M. Lam, and R. B. M. Huirne. 2009. Preferences of cost factors for mastitis management among Dutch dairy farmers using adaptive conjoint analysis. Prev. Vet. Med. 92:351-359.

Huijps, K., T. J. G. M. Lam, and H. Hogeveen. 2008. Costs of mastitis: Facts and perception. J. Dairy Res. 75:113-120.

Hultgren, J., and C. Svensson. 2009. Lifetime risk and cost of clinical mastitis in dairy cows in relation to heifer rearing conditions in southwest Sweden. J. Dairy Sci. 92:3274-3280.

ICBF. 2010. Irish Cattle Breeding Statistics. Irish Cattle Breeding Federation, Shinagh House, Bandon, Co. Cork.

International Dairy Federation. 1997. Recommendations for presentation of mastitis-related data. Bulletin No 321/1997. International Dairy Federation, Brussels, Belgium.

Kelly, P. 2009. A study of the somatic cell count (SCC) of Irish milk from herd management and environmental perspectives. $\mathrm{PhD}$ Thesis 10732. Dublin, University College Dublin, Ireland.

Kennedy, E., L. Shalloo, and F. Buckley. 2011. Optimising heifer replacement performance. Accessed Aug. 23, 2011. http://www. agresearch.teagasc.ie/moorepark/Articles/OptimisingReplacementHeiferPerformance_201101.pdf.

Klei, L., J. Yun, A. Sapru, J. Lynch, D. Barbano, D. Sears, and D. Galton. 1998. Effects of milk somatic cell count on cottage cheese yield and quality. J. Dairy Sci. 81:1205-1213.

Kossaibati, M. A., and R. J. Esslemont. 1997. The costs of production diseases in dairy herds in England. Vet. J. 154:41-51.

Larcombe, M., and R. Shephard 2004. Countdown Down Under Mastitis Model User's Guide. Dairy Australia, Victoria, Australia.

Ma, Y., C. Ryan, D. M. Barbano, D. M. Galton, M. A. Rudan, and K. J. Boor. 2000. Effects of somatic cell count on quality and shelf-life of pasteurized fluid milk. J. Dairy Sci. 83:264-274.
Malcolm, D., I. Hook, B. Montgomerie, A. Winkleman, S. Sim, and G. Brennan. 2005. The cost of mastitis. Dairy Insight Research 2005/2006 Final Report. National Mastitis Advisory Committee, Hamilton, New Zealand.

McCarthy, S., B. Horan, P. Dillon, P. O'Connor, M. Rath, and L. Shalloo. 2007. Economic comparison of divergent strains of Holstein-Friesian cows in various pasture-based production systems. J. Dairy Sci. 90:1493-1505.

More, S. J., K. McKenzie, J. O'Flaherty, M. L. Doherty, A. R. Cromie, and M. J. Magan. 2010. Setting priorities for non-regulatory animal health in Ireland: Results from an expert Policy Delphi study and a farmer priority identification survey. Prev. Vet. Med. 95:198-207.

O'Donnell, S., L. Shalloo, A. M. Butler, and B. Horan. 2008. A survey analysis of opportunities and limitations of Irish dairy farmers. J. Farm Manage. 13:419-434.

Olori, V. E., and P. J. B. Galesloot. 1999. Projection of partial lactation records and calculation of 305-day yields in the Republic of Ireland. Accessed Aug. 23, 2011. http://agtr.ilri.cgiar.org/library/ docs/Interbull/Bulletn22_files/Docs/OLORI.pdf.

Sayers, R. 2009. Disease risk analysis in the control of costly infectious diseases. Pages 114-127 in Proc. National Dairy Conference. Accessed May 8, 2012. http://www.teagasc.ie/publications/2009/20091120/index.asp.

Seegers, H., C. Fourichon, and F. Beaudeau. 2003. Production effects related to mastitis economics in dairy cattle herds. Vet. Res. 34:475-491.

Shalloo, L., P. Dillion, M. Rath, and M. Wallace. 2004. Description and validation of the Moorepark Dairy System Model. J. Dairy Sci. 87:1945-1959. 